\title{
Economic crisis, Keynesianism and structural imbalance in China
}

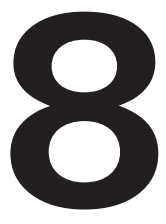

\section{Xiaolu Wang and Fan Gang}

\section{Economic crisis and demand insufficiency: theories and practices}

About 140 years ago, Karl Marx raised a famous explanation for economic crisis in On Capital (1867). He regarded the economic crises occurring periodically in the capitalist world as the result of the incompatibility between rapidly expanding production capacity and the mode of income distribution inherently associated with the capitalist system. Such incompatibility restricts the consumption capability of the majority of the people, and thus leads to overproduction. Cyclical economic crises that destroy the surplus production capacity are regarded as the only way to resume general equilibrium between aggregate supply and demand. This way of dealing with economic crises will, however, always brew the next one. Marx believed that this was an inherent and unsolvable conflict inside the capitalist economic system, and the highly developed production power could be finally released only if this system was replaced by one with public ownership and public distribution of income.

Although his conclusion was proved incorrect by the experience of the capitalist society unfolding later on, his judgment about demand insufficiency was validated more than half a century after On Capital was published. Altogether, there were seven economic crises in the Western world from the 1870s until the Great Depression in the 1930s, occurring on average once in every eight to 10 years. The most severe was the Great Depression that started in 1929, when the size of the US economy shrank by 30 per cent between 1929 and 1933 and the unemployment rate increased from 3 to 25 per cent. It took 10 years - until 1939-for the United States to restore its 1929 gross national product (GNP) (US Bureau of the Census 1975:126, 226). 
During this period of crisis, John M. Keynes published The General Theory of Employment, Interest and Money (1936), which stated the theory of insufficiency of effective demand. He argued that the marginal propensity to consumption was below unity and was usually affected by many objective and subjective factors. When total production was increasing, there needed to be expanding investment to fill the gap. There is, however, no automatic mechanism to keep investment equal to saving. Insufficiency of effective demand, overproduction and unemployment therefore occur from time to time. He further pointed out that in richer countries, the marginal propensity to consume was lower, so that this problem tended to occur more often.

The principle outlined by Keynes seems simple and reasonable. Unlike Marx, Keynes did not treat insufficiency of effective demand as an unsolvable flaw in the capitalist system. Instead, he suggested that the demand gap be filled by either increasing government expenditure or decreasing the interest rate to stimulate private investment. He pointed out that government expenditure could lift effective demand by more than the initial increase in expenditure via the multiplier effect. The higher the marginal propensity to consume, the greater is the multiplier-making, the expansionary fiscal policy more effective.

US President Franklin Roosevelt's 'New Deal' after 1933 coincided with Keynesian theory. The Roosevelt Administration expanded investment in the construction of infrastructure - such as roads, airports, schools and hospitals - held work-relief projects and established an unemployment benefit system. The decline of the US economy was soon moderated from -14.7 per cent in 1932 to -1.8 per cent in 1933 , and then returned to a positive growth rate, of 9.1 per cent, in 1934. After several years' recovery, by 1939, the economy had grown out of the crisis.

Roosevelt went beyond Keynes. The most distinctive measures were the establishment of the social security system in 1935 and the passing of the Fair Labor Standards Act in 1938. In addition, the Roosevelt Administration introduced progressive income taxes and death duties, which meant fairer income distribution between rich and poor. To some extent, these institutional innovations turned the United States from a traditional inchoate capitalist society to a welfare state on the basis of a free market. These institutional changes reduced income inequality, moderated social conflicts and lifted up total consumption. 
Keynes did not fully agree with those (such as Karl Marx) who treated demand insufficiency as a result of insufficient consumption. Keynes (1936) argued that increases in other investment and consumption could help to drive up effective demand although an increase in capital stock was far more valuable for a society. Once investment increased, consumption would automatically increase even without changing the propensity to consume. He also accepted, however, that the best solution might be to increase both investment and the propensity to consume at the same time. He argued that over-investment meant that any further investment would make losses, which could happen only in a situation in which all the capital goods were in abundant supply and there was full employment.

One important issue Keynes did not explore further, however, is that demand insufficiency situation itself - that is, a tendency for total investment to be less than total saving _ can be a result of market saturation caused by overcapacity. In this case, further investment-led, say, by lowering the interest rate-will lift aggregate demand only in the short run, before these investment projects are completed. After that, additional production capacity is created-thus, the demand-supply imbalance will appear again and could become more severe.

This is really an issue of saving-investment imbalance. Let's consider a simple two-sector model. Sector A produces consumer goods for the society and sector B produces capital goods for sector A and for itself for the renewal and possible expansion of capital stock. Each year the society consumes 80 per cent of its products in value and saves 20 per cent for investment. The total products of the society therefore consist of 80 per cent of consumer goods and 20 per cent of capital goods in value. Assuming the two sectors are equally productive and equally capital and labour intensive, and the economy is initially in equilibrium, sector A should share 80 per cent of the total capital stock and employment and B should share the remaining 20 per cent of the total capital stock and employment.

Now if the society increases the saving rate from 20 per cent to 50 per cent, consumption demand will decrease and there will be more financial resources available for investment. Meanwhile, the reduction in consumption demand will lead to an overcapacity in sector A, causing reallocation of capital and labour from A to B so that production comprises 50 per cent consumer goods and 50 per cent capital goods. 
If, however, the structural adjustment is completed in this way, sector $\mathrm{B}$ will at some future time have severe overcapacity, because the demand of sector A for capital goods will fall proportionally to its reduction in production - namely, a drop of 37.5 per cent $(1-50 \text { per cent } / 80 \text { per cent })^{1}$ and this will cause further demand reduction in sector B. A more likely situation is that the resource reallocation can be only partially completedthus, there will be insufficiency of demand in both sectors. As a result, there will be a reduction in total investment. This is because, with decreasing demand in both sectors, further investment would make losses.

In this situation, a loose monetary policy to stimulate investment can help to create short-term demand for capital goods in both sectors. However, increases in production capacity, once completed, will soon become overcapacity. The economy is unable to get out of the crisis, unless the propensity to consume resumes its initial level or the economy can export its capital goods to other countries without keeping a trade balance.

Now we add a public sector into the model and assume that the stimulatory investment is made only by the government and it invests only in a non-production public sector such as infrastructure. This will create a better and the economy will be lifted out of the recession. Without readjusting the saving and consumption rates, however, crisis will return when fiscal expansion stops. This is because, without expansionary government investment, the demand for capital goods will be less than the initial level. This will force the government to continue an expansionary fiscal policy with continued budgetary deficits, and will finally lead the economy into stagflation. This implies that production is restricted by the low propensity to consume, which is below its optimal level.

The policy implication is that when there is insufficient consumption, the typical Keynesian-style investment expansion or loose monetary policy is not enough, and institutional change and policy adjustment to stimulate consumption - such as establishing or improving social security and welfare systems - is necessary.

Before and after World War II, all industrialised countries completed the necessary institutional changes. While the basic market mechanisms remained, they changed the initial result of income distribution by establishing social security, social services and transfer payment systems. These entitled everyone to be educated, to be fairly paid and to be protected by medical care and pension systems. This reduced income inequality and largely changed the phenomenon of consumption insufficiency common 
in the old capitalist world. This moderated the traditional mechanism causing economic cycles.

How to weigh the advantages and disadvantages between social welfare policies and a free market, or between equality and efficiency, remains a hot topic of debate to this day-for which a common solution has not been found. From a historical perspective, however, most informed people agree that the institutional innovation in a certain level of social security and income redistribution in industrialised countries brought these countries new life in the twentieth century.

\section{Over-consumption in the United States and over-saving in China: two types of imbalance}

In terms of building and developing the social welfare system, the United States did not go as far as European countries. It retained large income inequality. The most recently available Gini coefficient for the United States is 0.408 (World Bank 2008), which indicates it has the largest income inequality in the industrialised world.

There were two basic elements enabling the United States to avoid severe crisis between the Great Depression of the 1930s and the current financial crisis.

First, the United States was heavily involved in World War II in the 1940s, the Korean War in the 1950s, the Vietnam War in the 1960s, the Gulf and Kosovo wars in the 1990s and the Afghanistan and Iraq wars in the 2000s, and conducted an arms race and arms exports during (and after) the Cold War. Arms demand digested the United States' expanding production capacity and largely moderated its demand insufficiency problem.

Second, for a long time, excessive borrowing has sustained an expansion of consumption in the United States. In 2007, personal consumption accounted for 70 per cent of gross domestic product (GDP) - twice as high as that in China-and total consumption accounted for 86 per cent of GDP. The net saving rate in the United States was -1.7 per cent and the outstanding debt of US households accumulated to US\$13.8 trillion, equivalent to total US GDP, in 2007. Adding government, financial and non-financial business debt, total outstanding debt amounted to US\$47.9 trillion-equal to 3.5 times US GDP in 2007 (CEIC 2009; Roach 2008). Table 8.1 presents data showing the levels of outstanding US debt and its 
structure. Sub-prime loans were securitised and sold to other countries via 'financial innovation', which formed the basis of worldwide financial bubbles and finally caused the global financial crisis.

\section{Table 8.1 Outstanding debt in the United States (US\$trillion)}

\begin{tabular}{l|c|c|c|c|c|c|c}
\hline Year & Government & Household & $\begin{array}{c}\text { Non- } \\
\text { financial } \\
\text { business }\end{array}$ & $\begin{array}{c}\text { Financial } \\
\text { sector }\end{array}$ & Sum & GDP & $\begin{array}{c}\text { Debt/GDP } \\
(\%)\end{array}$ \\
\hline 1950 & 0.2 & 0.1 & 0.1 & & & 0.3 & \\
\hline 1970 & 0.5 & 0.5 & 0.5 & 0.1 & 1.6 & 1.0 & 149 \\
\hline 1990 & 3.5 & 3.6 & 3.8 & 2.6 & 13.5 & 5.8 & 232 \\
\hline 2007 & 7.3 & 13.8 & 10.6 & 16.2 & 47.9 & 13.8 & 347 \\
\hline
\end{tabular}

Sources: CEIC n.d., CEIC Database, CEIC Data Company Limited, <www.ceicdata.com> ; United States Bureau of the Census 1975, Historical Statistics of the United States: Colonial times to 1970, United States Bureau of the Census, Washington, DC, Part 2, pp. 973, 989.

In general, the United States transformed itself from over-production to an over-consumption by large levels of military spending and excessive borrowing. Neither of these were sustainable. The unbalanced structure of the United States could be maintained for so long was partially related to another type of structural imbalance in China.

In contrast with the US economy, China retained a very high saving rate and correspondingly low consumption. China's massive exports filled the US gap between consumption and production. China's large foreign exchange reserves financed US consumption and investment based on borrowing. Conversely, without the over-consumption in the United States, China's rapidly expanding production capacity would have been obstructed earlier by the insufficiency of domestic demand.

In the past 50 years, there has been a continued decrease in China's consumption rate and a continued increase in the saving rate The rate of final consumption in GDP dropped rapidly between 2000 and 2007, from 62 per cent to 49 per cent. The household consumption rate dropped from 46 per cent to 35 per cent during the same period. The recent consumption rate is the lowest in the world, and is far lower than that in most countries. Although investment has grown rapidly, it has lagged behind the growth in savings. Due to the insufficiency of domestic demand, firms have relied more and more on the international market for sales and the economy for growth. This has formed a complementary economic relationship between China and the United States. The opposite trend of changing saving and consumption rates in China and the United States is shown in Figures 8.1a and 8.1b. 
Figure 8.1a Final consumption rate and gross saving rate in China, 1952-2008 (per cent)

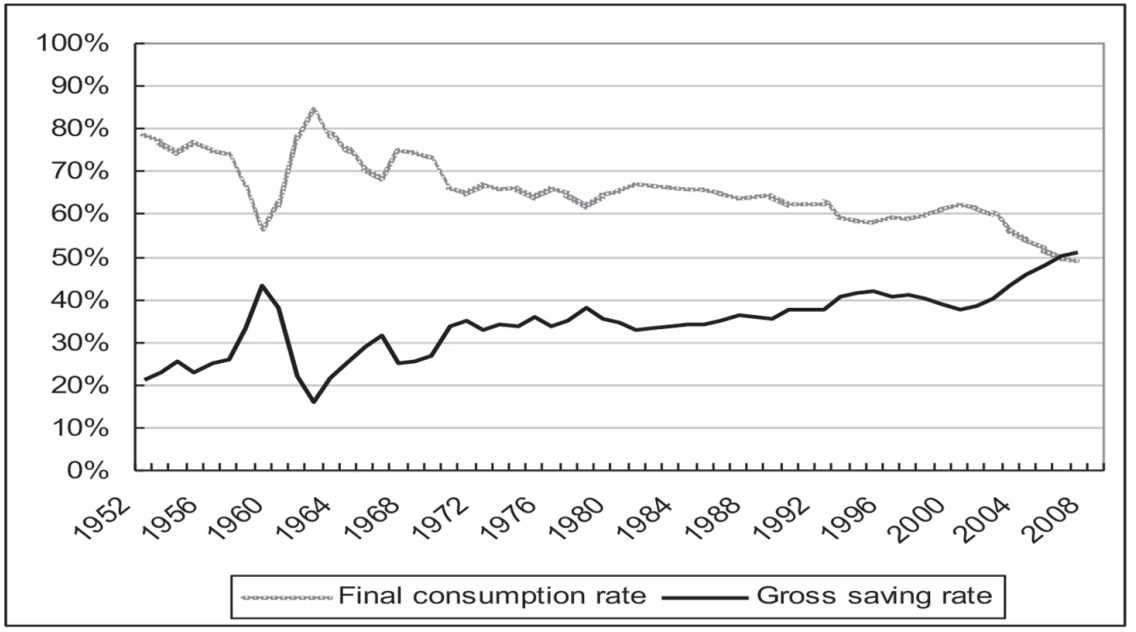

Figure 8.1b Final consumption rate and gross saving rate in the United States, 1952-2008 (per cent)

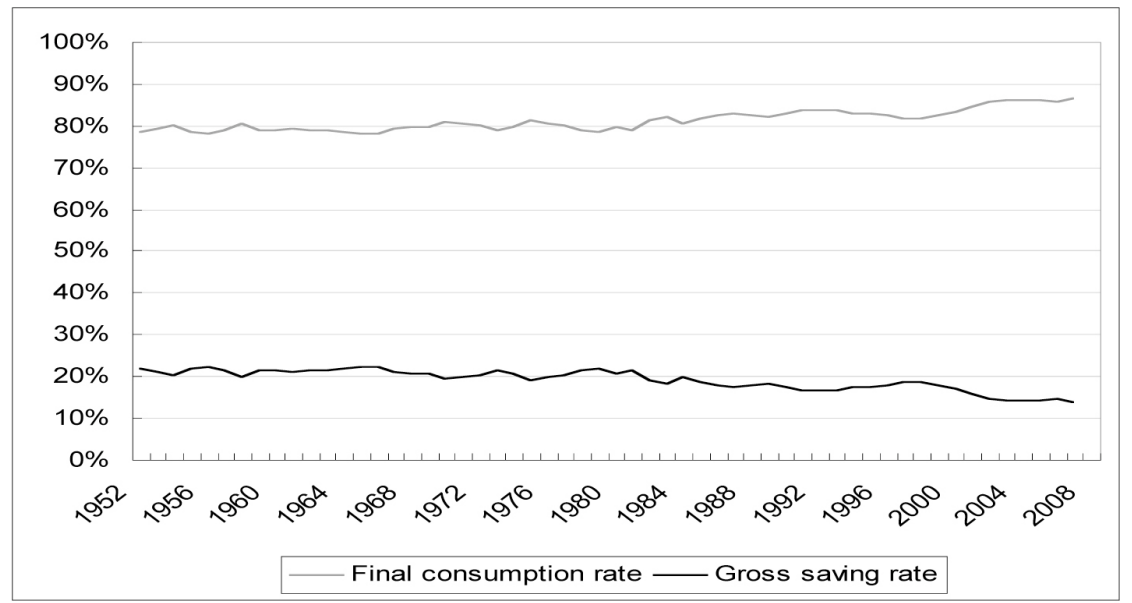

Note: Final consumption rate and gross saving rate are the ratios of final consumption and gross savings to GDP.

Sources: National Bureau of Statistics (NBS) various years, China Statistical Yearbook, China Statistics Press, Beijing; CEIC n.d., CEIC Database, CEIC Data Company Limited, $<$ www.ceicdata.com $>$ 
In 2007, China's exports to the United States accounted for 19 per cent of its total exports. China's bilateral trade surplus with the United States (US\$163 billion) accounted for 62 per cent of China's trade surplus and 5 per cent of China's GDP. According to the US statistics, the US-China trade deficit is even larger (US\$256 billion), because it includes trade via Hong Kong; it accounted for 36 per cent of the total trade deficit in the United States. This indicates a close relationship between China and the United States with regard to domestic imbalances. Net exports (as a percentage of GDP for each country) for China and the United States have changed radically in the past two decades (Figure 8.2). They have exhibited a kind of symmetrical pattern in the past decade, which indicates the increasing bilateral dependency between the two countries.

\section{Figure 8.2 Changing net exports between China and the United States, 1952-2008 (percentage of total GDP)}

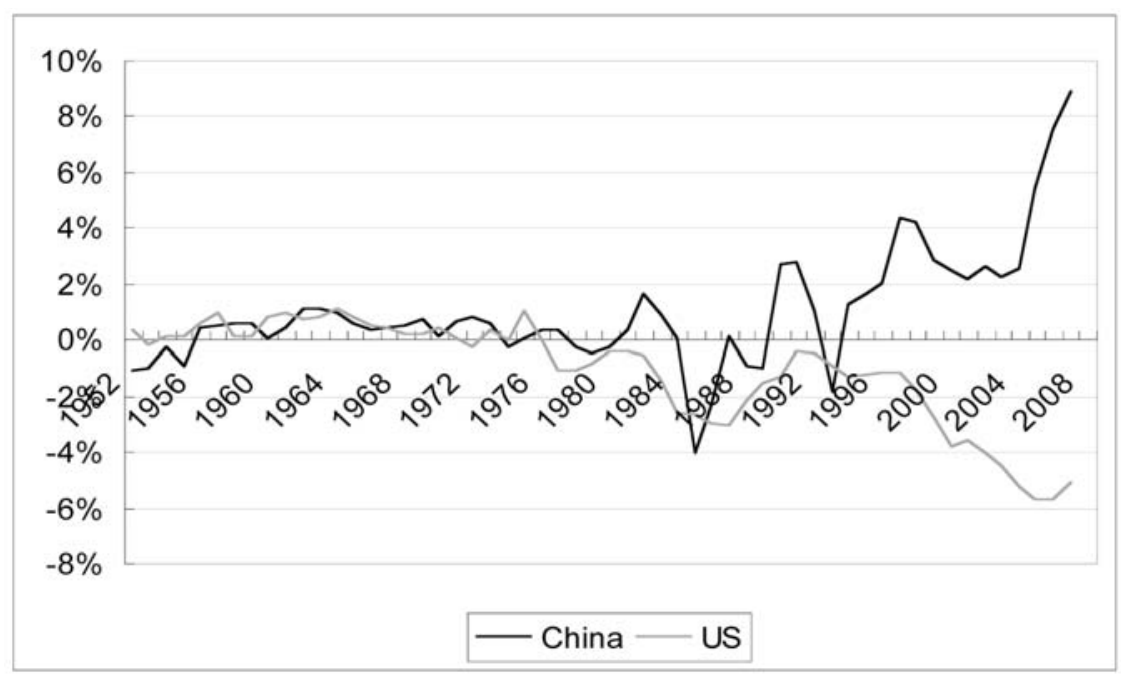

Note: GDP in each country as 100 per cent.

Sources: National Bureau of Statistics (NBS) various years, China Statistical Yearbook, China Statistics Press, Beijing; CEIC n.d., CEIC Database, CEIC Data Company Limited, $<$ www.ceicdata.com $>$

This kind of interdependence, however, can no longer be sustained. The US consumption bubble has burst and there must be a major structural adjustment in the United States to increase saving and decrease borrowing and consumption to more sustainable levels. This will mean a contraction of the US commodity market for a long period. The current 
situation in the world economy indicates that recovery in other major industrialised countries will also follow a long time frame. The Chinese economy therefore has to change its growth pattern to domestic demandbased growth. Unless domestic consumption can be raised sufficiently, the State's stimulus package of CNY4 trillion announced in November 2008 might work only in the short run.

\section{Why consumption is insufficient in China}

The modern history of the decreasing consumption rate in China can be divided into two phases. During the central planning period (1952-77), the rate of final consumption in GDP fell from 79 to 65 per cent (NBS 2005). This was a result of forced government saving - that is, using government power to depress wages and the prices of agricultural products and to concentrate resources on government investment in industry. This did not lead to overproduction and insufficiency of consumption demand; on the contrary, there were always supply shortages. This was because, under the centrally planned system of the time, production inefficiency and investment failures ironically acted to remove the potential problem of overcapacity.

Decreases in the consumption rate in the market-oriented reform period (after 1978) were led by a different mechanism. This led in the opposite direction to the contemporary structural imbalance in the United States, but was consistent with that in Western countries before the Great Depression in 1929.

There are several reasons for the decreases in consumption in China. First, as described in the Lewis model (1954), China had an 'unlimited supply' of labour during the reform period. There was continued labour migration from rural to urban sectors. About 140 million rural migrant workers are currently working in urban areas. With total output growing rapidly, the abundant labour supply prevented wages from increasing, which resulted in decreases of both labour shares and household consumption shares in GDP. This trend was moderated only in recent years, due to a reduction of surplus labour in rural areas, but unemployment pressure was reinforced after 2008 by the global financial crisis. From 1985 to 2005, real GDP per capita increased 5 times, whereas the real wage rate in the private sector increased only 3.6 times, and real consumption per capita increased only 3.5 times (NBS 2008). 
Second, slower growth of labour wages and faster growth of non-labour incomes resulted in widening income inequality. In this situation, national income is distributed more towards higher-income resident groups, whose saving rate is significantly higher than low-income residents. During the reform period (1978-2005), the income Gini coefficient in China increased from 0.32 to 0.47 (World Bank 2008). The large and widening income inequality automatically results in an increasing share of saving and decreasing share of consumption in GDP. There is no such market mechanism to guarantee that labour income and household consumption will grow in line with output.

Third, while employment and wage determination mechanisms changed from government dominated to the influence of market forces, legislation on labour protection and the development of social security and public service systems lagged behind in China. These institutional innovations, as complements to the market system, were well developed in Europe and North America more than half a century ago. Until 2007, the basic pension insurance and urban medical care insurance systems covered only 201 million and 180 million people, respectively, accounting for only 34 and 30 per cent, respectively, of the urban population. The unemployment insurance system covered only 116 million workers, accounting for 40 per cent of total urban employment. None of these systems covers rural residents. With uncertainties or fear about ageing and future illness, unemployment, and so on, the majority of people are forced to increase their savings.

Fourth, in recent years, the increasing national saving rate has been due mainly to rapid increases in enterprise savings, particularly the savings of state-owned enterprises (SOEs), enterprises operating in natural resources and those with monopolistic power. This is related to the fact that there is no SOE dividend distribution system or a proper taxation system on returns of natural resources - thus, huge undistributed profits are retained in enterprises that have contributed to the high level of investment in China (Fan et al. 2009).

Fifth, in those industries operating in the natural resources sector or that have a natural or state monopoly (or oligopoly) - for example, power generation and supply, telecommunications, banking and insurance, oil and natural gas, tobacco, and so on-a social optimum is not automatically achieved via market competition. Without appropriate regulation and social monitoring, income distribution will deteriorate towards inequality 
and inequity. Some estimates suggest the income differential between people engaged in state-owned and other sectors is 5 to ten times (Wang 2007).

Sixth, governments at the provincial and municipal level have the incentive to promote development of large and capital-intensive firms to achieve higher growth performance-a policy that is unfavourable to small and labour-intensive enterprises. The large bank-dominated financial sector also disadvantages small enterprises in external finance. These reduced employment opportunities and lowered returns to labour therefore contribute to decreases in the consumption rate. According to the two national industrial (economic) censuses in 1995 and 2004, the share of large and medium industrial enterprises in gross industrial output value during this period increased from 43.6 to 60 per cent, and their employment share increased from 33 to 37.7 per cent. Correspondingly, output shares and employment shares of small enterprises decreased from 56.4 to 40 per cent and from 67 to 62 per cent, respectively. The number of small enterprises decreased from 1.83 to 1.35 million, while their employment decreased from 79 to 58 million. ${ }^{2}$

According to Keynesian theory, consumption insufficiency can be supplemented by higher investment leading to expansionary fiscal or monetary policy. As discussed earlier in this chapter, however, after a short period, this investment will lead to an increase in production capacity. Its effect on consumption demand will be restricted to a certain level by the marginal propensity to consume, thus further enlarging the gap between aggregate supply and effective demand. Unless net exports are expanding, economic growth cannot be maintained.

This situation emerged in China over the past decade. In the period 2000-07, the real growth rates of final consumption and urban and rural per capita incomes were lower than the GDP growth rate (Table 8.2). In particular, real consumption growth was slower than GDP growth by 2-5 percentage points in most years, resulting in a reduction in the rate of final consumption in GDP from 62 to 49 per cent. As the other side of the coin, gross saving grew at a much faster rate than GDP growth in most years. Although capital formation grew more rapidly than GDP, it was not as high as that of savings growth in most years, because the existence of overcapacity put limits on opportunities for profitable investment. This indicates an insufficiency of domestic demand. Trends in the loan/deposit ratio in financial institutions also point to low growth in domestic demand. 
This ratio decreased from 80 to 67 per cent during the 2000-07 period, indicating accumulation of a large amount of unused financial resources in banks, which could not be fully utilised for investment.

\section{Table 8.2 Structural imbalance in China: growth of GDP and its components (per cent)}

\begin{tabular}{l|c|c|c|c|c|c|c|c}
\hline Year & $\mathbf{2 0 0 0}$ & $\mathbf{2 0 0 1}$ & $\mathbf{2 0 0 2}$ & $\mathbf{2 0 0 3}$ & $\mathbf{2 0 0 4}$ & $\mathbf{2 0 0 5}$ & $\mathbf{2 0 0 6}$ & $\mathbf{2 0 0 7}$ \\
\hline GDP growth $^{\mathrm{a}}$ & 8.4 & 8.3 & 9.1 & 10.0 & 10.1 & 10.4 & 11.6 & 13.0 \\
\hline Final consumption & 8.4 & 6.5 & 6.6 & 5.3 & 5.1 & 8.3 & 9.1 & 10.4 \\
\hline Gross saving & 2.8 & 10.8 & 14.9 & 18.1 & 16.2 & 19.5 & 18.0 & 15.4 \\
\hline Capital formation $^{\text {Net export }}$ & 3.6 & 11.8 & 13.9 & 19.7 & 15.6 & 12.4 & 13.0 & 12.2 \\
\hline $\begin{array}{l}\text { Urban per capita } \\
\text { income growth }^{\mathrm{b}}\end{array}$ & -7.7 & -4.7 & 32.3 & -5.9 & 27.7 & 141.5 & 57.2 & 33.5 \\
\hline $\begin{array}{l}\text { Rural per capita } \\
\text { income growth }\end{array}$ & 5.5 & 9.5 & 11.1 & 8.9 & 7.7 & 9.6 & 10.4 & 12.2 \\
\hline Export growth $^{\mathrm{b}}$ & 2.0 & 4.2 & 5.0 & 4.3 & 6.8 & 8.5 & 8.6 & 9.5 \\
\hline Final consumption/GDP & 62.3 & 61.4 & 59.6 & 56.8 & 54.3 & 51.8 & 49.9 & 48.8 \\
\hline Loan/deposit $^{\mathrm{d}}$ & 80.3 & 78.2 & 76.8 & 76.4 & 73.8 & 67.8 & 67.2 & 67.2 \\
\hline Net export/GDP & 2.4 & 2.1 & 2.6 & 2.2 & 2.5 & 5.4 & 7.5 & 8.9 \\
\hline
\end{tabular}

a Final consumption, capital formation and net export (of goods and services) are the three components of the GDP-by-expenditure approach (NBS various years); gross saving is defined as GDP-final consumption; their growth rates are deflated by the authors using the implicit GDP deflator of the NBS (various years).

b Urban disposable income per capita and rural net income per capita, respectively.

c Measured in US dollars in current prices.

d The ratio of total loans to total deposits in financial institutions.

Sources: Calculated from National Bureau of Statistics (NBS) various years, China Statistical Yearbook, China Statistics Press, Beijing.

The insufficiency of domestic demand pushed firms to expand their exports to overseas markets. Net exports have grown dramatically in recent years, lifting the ratio of net exports to GDP from about 2 to close to 9 per cent between 2001 and 2007.

Data in Table 8.2 indicate an expanding insufficiency of domestic demand in China in recent years, which has been compensated by rapid net export growth. Economic growth was therefore maintained at a high rate of about 10 per cent. This relied on the competitiveness of Chinese products in world markets and also from the over-consumption in the United States.

During the past decade, export growth has remained above 20 per cent. Affected by the financial crisis, it dropped sharply to 4.3 per cent in 
the year to the fourth quarter of 2008 , then to -19.7 per cent in the year to the first quarter of 2009. Exports decreased dramatically in China in 2008-09 (Figure 8.3). The GDP growth rate fell from 13 per cent in 2007 to 9 per cent in 2008 - due mainly to lower export growth - and then to 6.1 per cent in the year to the first quarter of 2009. is the latter was the lowest since the 1998 East Asian financial crisis. The recent economic situation indicates that the impact of the global financial crisis will not quickly fade. After the crisis, only a transformation in the growth pattern in China from heavy dependence on external demand to domestic-based demand will provide a basis for continued rapid growth.

\section{Figure 8.3 Falling exports in China amid the economic crisis, 2008-09}

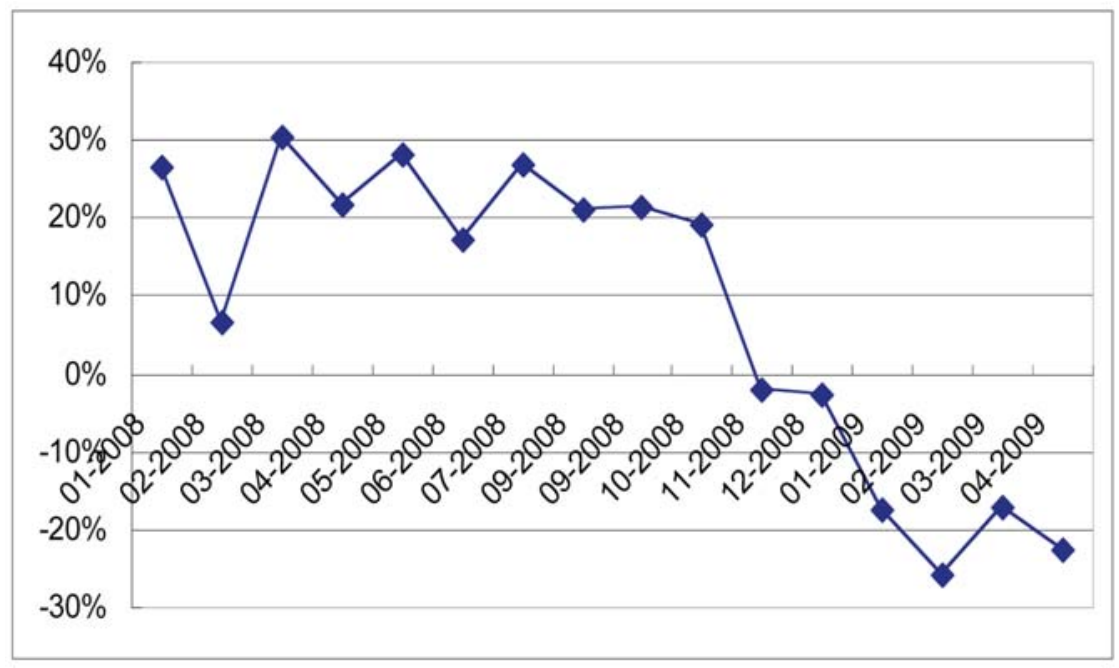

Note: Year-on year growth rate in US dollars, at current prices.

Source: General Administration of Customs of the People's Republic of China 2009, Customs Statistical Data, General Administration of Customs web site, < http://www.customs.gov.cn/>

The Chinese Government in November, 2008 announced a CNY4 trillion (US\$586 billion) investment package for economic stimulation in 2009-10, accounting for roughly 6 per cent of GDP each year. Although the situation in the international market is still serious, we can expect an increase in the economic growth rate in China in the second half of 2009, and can be quite certain that the Chinese economy will recover from the crisis sooner than the industrialised countries. The question, however, is whether the structural imbalance between saving and consumption in 
China can be corrected after the stimulus package has been implemented. If not, the fiscal investment might play a role only in the short run and there will still be a threat of weak demand in the future. The question of whether economic growth can be sustained in the longer term remains unanswered.

\section{The future of the Chinese economy}

The above discussion leads to a conclusion that the basic problem for China's economic growth is not a short-run issue; it is the sustainability of rapid growth in the longer term. Sustainable growth has to be based mainly on domestic demand. Therefore the saving-consumption imbalance has to be corrected through some fundamental changes. The most important of these changes are improvements in the social security and public service systems, reforms of the government financial and taxation systems, improvements in the business environment for small enterprises and for employment and acceleration of the urbanisation process. Without such institutional reforms, the demand inefficiency problem will not be solved.

One should note the significant policy adjustment made by the Chinese Government in recent years towards reducing income inequality and improving public services. These include the abolition of the agricultural tax (2004-06), exemption from school fees for the nine-year urban and rural compulsory education system (2006-07), the establishment of an overall rural minimum living allowance system (2006-07) and a rural cooperative medical service system (2006-08), passing into legislation the Labour Contract Law (2008), and so on. These new policies have been effective. As indicated in Table 8.2, consumption growth in 2003-04 was about 5 per cent - only half the economic growth rate. It has increased to 8-10 per cent since 2005, although it is still below the GDP growth rate by more than 2 percentage points. With this trend unchanged, China will continue to suffer from demand insufficiency.

To rebalance the saving-consumption structure and to get the economy growing strongly again, it is necessary to achieve faster consumption growth than GDP growth for a period, so that the final consumption rate can be lifted from the current 49 per cent to about 60 per cent or higher. Household consumption should also be increased from the current 35 per cent, by at least 10 percentage points. A 60 per cent final consumption rate is still significantly lower than the world average - 78 per cent in 2006 
(World Bank 2008)_-but might be enough to offset the negative impact of the world economic crisis.

To rebalance the saving-consumption structure, the following additional policy adjustment and reforms are essential.

First, the current incomplete and regionally segmented social security systems should be unified nationwide and expanded to cover all urban residents in a relatively short period. At the current level of economic development, this system could provide only a minimum level of security to everyone. Supplemental social security and commercial insurance in different regions should be encouraged, especially for the better-developed regions and higher-income residents; however, the unified system will insure all people's basic security, including the 140 million 'floating' rural workers in urban areas. The system should be gradually extended to cover rural residents.

Second, public services in education and health care should be further improved. Upgrading the current nine-year compulsory education to a 12-year system will not be an unaffordable burden, but will provide great returns to the nation in the future. In particular, secondary vocational education and job training programs should be further developed.

Third, low-rent government housing is now provided only to small numbers of low-income urban residents. It can be expanded in the coming years for all low-income families, including rural-urban migrant workers. The current government-subsidised 'affordable housing' is not really affordable for low-income people and actually benefits some middle or higher-income people. These government resources should be redirected entirely to building low-rental housing for low-income families.

Fourth, further financial sector reform is needed to lower the threshold for the development of non-state - especially small-financial institutions. It is particularly important for the finance and development of the small enterprise sector and the creation of employment opportunities.

Fifth, sectors with a state monopoly should be reformed. Market competition should be extended further and the regulatory and monitoring systems should be improved.

Sixth, the government finance and taxation systems should be reformed to impose a resource tax, to establish a dividend distribution system for SOEs, to rearrange central-regional fiscal relations to enable provincial, 
municipal and local governments to perform their functions, to unify the return distribution system for land selling and to improve the regulation and monitoring systems for the management of public resources - in particular, to make them more transparent and accountable.

With more balanced income distribution and saving-consumption growth, China can expect sustainable economic growth in the long run.

\section{References}

CEIC 2009, CEIC Database, CEIC Data Company Limited, $<$ www.ceicdata.com $>$

Fan, G., Wei, Q. and Liu, P. 2009, Internal-external balance and fiscaltaxation reform in China, Unpublished manuscript.

General Administration of Customs of the People's Republic of China 2009, Customs Statistical Data, General Administration of Customs web site, $<$ http://www.customs.gov.cn>

Keynes, J. M. 1936, General Theory of Employment, Interest and Money, Macmillan, London.

Lewis, W. A. 1954, 'Economic development with unlimited supplies of labor', Manchester School of Economic and Social Studies, vol. XXII (May), pp. 139-91.

Marx, K. 1867, Das Kapital: Kritik der politischen oekonomie. Volume I, [Chinese translation 1975], People's Publisher, Beijing.

1895, Das Kapital: Kritik der politischen oekonomie. Volume III, [Chinese translation 1975], People's Publisher, Beijing.

National Bureau of Statistics (NBS) 2005, China Statistical Yearbook 2005, China Statistics Press, Beijing.

2008, China Statistical Yearbook 2008, China Statistics Press, Beijing.

Beijing.

Roach, S. 2008, Keynote speech to China Development Forum, Beijing. 
United States Bureau of the Census 1975, Historical Statistics of the United States: Colonial times to 1970, parts 1-2, United States Bureau of the Census, Washington, DC.

Wang, X. L. 2007, 'Grey income and income inequality in China', [in Chinese], Comparative Studies, vol. 38, China CITIC Press, Beijing.

World Bank 2008, World Development Indicators 2008, The World Bank, Washington, DC.

\section{Endnotes}

1. This is under the assumption of simple linear production technology. If we assume a technology with diminishing marginal products of capital and labour, the drop in demand for capital goods will be even greater.

2. The authors have recalculated the 1995 data to exclude household firms in the industrial sector, so that the data series is made consistent with the 2004 data. Still, there are some differences in data definition between the two censuses; therefore the data are not fully comparable. These comparisons show only the direction and an approximate scale of the changes during this period. 